\title{
MENGGAGAS DAKWAH KORESPONDENSI NABI MUHAMMAD SAW
}

\author{
Abdul Ghoni \\ Fakultas Dakwah dan Komunikasi UIN Walisongo Semarang \\ Email: abdul.ghoni@walisongo.ac.id
}

\begin{abstract}
This type of research is qualitative by using historical approach. Technique of collecting data in this research is library research (literature study). The results of the study as follows; the background of sending letters as a medium of propaganda by Rasulullah SAW. to the kings of his time were carried out for several reasons from theological and political aspects. The propagation format of Rasulullah SAW. which was sent to the kings and rulers of the time was astonishing, as evidenced by several things, namely; a). The Prophet's Epistles. always preceded the sentence Basmalah, b) The composition of the sentence in the letter of the Messenger of Allah. always preceded the phrase "From Muhammad the servant of God and his messenger", c). The contents of the letter of the Prophet SAW. worth persuasively invites kings to embrace Islam. From the elaboration of the correspondence of Prophet Muhammad SAW this should da'i be able to apply the information media as part of the dakwah correspondence.

Jenis penelitian ini kualitatif dengan menggunakan pendekatan historis. Teknik pengumpulan data dalam penelitian ini adalah library research (studi kepustakaan). Hasil penelitian sebagai berikut; latarbelakang pengiriman surat sebagai media dakwah oleh Rasulullah SAW. kepada para raja pada masanya dilakukan dengan beberapa alasan dari aspek teologis dan politis. Format surat dakwah Rasulullah SAW. yang dikirimkan kepada para raja dan penguasa saat itu sangatlah menakjubkan, yang dibuktikan dengan beberapa hal, yaitu; a). Surat-surat Rasulullah saw. selalu didahului kalimat Basmalah, b) Susunan kalimat di dalam surat Rasulullah saw. selalu didahului kalimat "Dari Muhammad hamba Allah dan utusan-Nya", c). Isi surat Rasulullah SAW. bernilai persuasif mengajak para raja untuk memeluk agama Islam. Dari elaborasi korespondensi Nabi Muhammad SAW ini seyogyanya para da'i mampu menerapkan media informasi sebagai bagian dari dakwah korespondensi.
\end{abstract}

Kata Kunci : Korespondensi dan Dakwah Nabi Muhammad SAW 


\section{A. Pendahuluan}

Salah satu bentuk media dalam berdakwah adalah melalui surat. Surat dakwah itu sendiri merupakan salah satu media dakwah dalam bentuk tulisan dan wahana untuk mengajak beriman bagi kaum tertentu. ${ }^{1}$ Saat ini, dakwah dengan media tulisan menjadi bagian penting dalam proses dakwah. Hal ini ditunjukkan dengan semakin menjamurnya majalah, surat kabar, hingga buletin-buletin Islami. Selain itu akses mengenai berita dunia Islam juga sangat mudah diperoleh melalui perkembangan teknologi informasi, yaitu internet. Dakwah melalui tulisan tidak hanya menjadi ekspresi jiwa intelektualitas dari umat Islam, namun menjadi wujud begitu pentingnya dakwah melalui surat.

Dakwah melalui media semacam ini bukanlah cara yang baru dalam tradisi dakwah Islam. Figur sentral yang pernah melaksanakan justru sang agent of change, Nabi Muhammad SAW. Beliau menggunakan media dakwah melalui surat atau korespondensi yang ditujukan kepada para raja dan penguasa non-muslim saat itu. Secara tidak langsung Rasulullah SAW telah mencontohkan kepada umatnya dalam berdakwah, dimana media surat kepada para raja yang disampaikan melalui duta-duta Rasulullah SAW telah dilakukannya. ${ }^{2}$

Fakta historis mencatat, pasca diberlakukannya perjanjian Hudaibiyah3, Nabi Muhammad SAW sangat gencar mengajak para raja di negeri seberang untuk memeluk agama Islam. ${ }^{4}$ Setelah perjanjian Hudaibiyah, keadaan menjadi tenang dan dakwah Islam mendapat ruang gerak secara progresif. Rasulullah SAW menulis surat kepada para raja-raja dan para pemimpin Arab, mengajak mereka masuk Islam, menuju jalan Tuhannya dengan cara bijaksana dan nasihat baik. Beliau sangat memperhatikan hal ini, sehingga beliau memperlakukan dakwah melalui surat sedemikian rupa. Dalam melaksanakan dakwah melalui surat,

1 Hatta dkk, Ahmad., The Great Story Of Muhammad SAW., (Jakarta: Maghfirah Pustaka, 2011) hlm.435

2 Ilaihi, Wahyu dan Harjani Hefni, Komunikasi Dakwah, (Bandung: PT. Remaja Rosda Karya, 2010). hlm. 63

3 Perjanjian Hudaibiyah oleh sebagian besar kalangan saat itu dinilai sebagai kesepakatan yang merugikan bagi kalangan Islam, karena secara eksplisit butir-butir perjanjian itu merugikan umat Islam. Namun dsinilah letak kejelian Rasulullah yag mampu melihat keuntungan dari disepakatinya perjanjian tersebut, dimana Islam mempunyai peluang untuk diperkenalkan kepada masyarakat atau wilayah di luar Jazirah Arab. Lihat, Munawwar Khalil, Kelengkapan Tarikh Nabi Muhammad, (Jakarta : Bulan Bintang) 1996, hlm. 798.

4 Ja'far Subhani, Ar-Risalah: Sejarah Kehidupan Rasulullah SAW, Penerjemah: Muhammad Hasyim dan Meth Kieraha, (Jakarta: Lentera, 2000) hlm.481 
Rasulullah memilih orang yang layak untuk diutus dalam menyampaikan suratnya, memilih utusan yang mengetahui bahasa dan kultur Negara obyek dan sebagainya. ${ }^{5}$

Dengan strategi yang dilakukan, diharapkan effektifitas dakwah melalui media ini berjalan mulus. Beberapa pemimpin dan raja-raja yang mendapat surat dakwah dari Nabi Muhammad menurut Ibnu Hisyam antara lain Raja Negus "Najasyi" di Abbessinia (Ethiopia sekarang ini), Raja Heraclius (Kaisar Imperium Romawi yang berpusat di Konstatinopel atau Byzantium), Raja Khosrou II (Kisra Abrawaiz penguasa Persia), dan Raja Muqauqis penguasa Koptik (Qibthi wilayah Mesir). Kesemuanya merupakan penguasa wilayah yang masih beragama selain Islam dan dijadikan sebagai obyek dakwah melalui media surat. ${ }^{6}$ Artikel ini berusaha mengelaborasikan korespondensi Nabi Muhammad sebagai bagian dari dakwah kepada Raja-raja pada masanya di atas.

\section{B. Dakwah Korespondesi}

Kata dakwah telah menjadi salah satu kosa kata bahasa Indonesia, yang berarti mengajak (menyeru) untuk mempelajari dan mengamalkan ajaran Islam. ${ }^{7}$ Dalam bahasa Arab berakar kata dengan huruf 9 (dal, 'ain dan waw) yang berarti dasar kecenderungan sesuatu disebabkan suara dan kata-kata. ${ }^{8}$ Dari akar kata ini terangkai menjadi asal kata $d a^{\prime} a-y a d^{\prime} u$ da'watan, (fiil naqish) berarti "menyeru, memanggil, mengajak, dan menjamu", atau kata da'a-yad'u-du'aan, dakwahu, berarti "menyeru akan dia". ${ }^{9}$ Kemudian dari kata al-da'i, jamak da'atun, mu'anasnya da'iyatun, jamak da'iyatun, berarti orang yang mengajak manusia ke agama dan kepada mazhabnya. ${ }^{10}$

5 Abul Hasan Ali Al-Hasan An-Nadwi, Shirah Nabawiyah, Sejarah Lengkap Nabi Muhammad SAW, Cet. ke-6, Penerjemah: M. Halabi Hamdi dkk., (Yogyakarta: Darul Manar, 2011) hlm. 341 hlm. 556

${ }^{6}$ Abdul Malik Ibnu Hisyam, Shirah Nabawiyah, (Beirut: Dar al Kutub Al-Ilmiah, 1971)

7 Departemen Pendidikan dan Kebudayaan, Kamus Besar Bahasa Indonesia, (Jakarta: Balai Pustaka, 1990) hlm. 181

8 Abi al-Husain Ahmad bin Faris bin Zakariya, Mu'jam Maqayis al-Lughah, (Mesir: Mushthafa al-Babi al-Halabi, 1389 H/1969 M), Juz II, hlm. 279

9 Yunus, Mahmud, Kamus Arab Indonesia, (Jakarta: Yayasan Penyelenggara Penterjemah/Penafsir Al-Qur'an, 1973) hlm.127

10 Ali al-Najir, Ibrahim Mushthafa, Ahmad Hasan al-Zayat, Hamid Abd al-Qadir dan Muhammad, al-Mu'jam al-Wasith, (Istambul-Turki: Dar al-Dakwah, 1989) hlm. 286 
Kata-kata tersebut, terutama bila dilihat dari segi penggunaannya dalam konteks ayat-ayat al-Qur'an, tampak lebih tertuju kepada ajakan (mengajak) kebaikan, apalagi kalau dilihat pemakaian ayat-ayat dakwah dalam al-Qur'an, seperti surat Ali Imran ayat 104. Kalimat يدعو ن dalam ayat ini menurut al-Alusi, mengandung pengertian ajakan kepada kebaikan; yakni ajakan kepada kepentingan perbaikan keagamaan (Islam) dan keduniaan. Dalam rangka itu, sehingga kalimat itu di-'athaf-kan kepadanya kalimat berikutnya. ${ }^{11}$

Dakwah secara etimologis, menurut Bahi al-Khuli mengatakan, dakwah adalah memindahkan suatu situasi manusia kepada situasi yang lebih baik. ${ }^{12}$ Pendapat ini lebih didasarkan pada perubahan situasi obyek dakwah. Berbeda dengan Muhammad 'Abduh (w. 1905 M/1323 H) yang mengistilahkan dakwah dengan ishlah, yaitu memperbaiki keadaan kaum muslimin dan memberi petunjuk kepada orang-orang kafir untuk memeluk Islam. ${ }^{13}$ Abduh mensinyalir perubahan yang ada lebih pada aspek agama.

Sedangkan Abu Bakar Zakaria mengatakan, dakwah ialah usaha para ulama dan orang yang memiliki pengetahuan tentang agama (Islam) dengan memberi pengajaran kepada masyarakat akan hal-hal yang dapat menyadarkan mereka terhadap urusan keagamaan dan keduniaannya sesuai dengan kemampuan yang dimiliki. ${ }^{14}$ Zakaria menyoroti dakwah dalam praktek, dimana unsur dakwah sudah dimasukkan dalam definisi yang disusunnya, sekaligus tujuan dakwah itu sendiri.

Dari beberapa definisi di atas dapat diartikan bahwa dakwah adalah sebagai berikut:

a. Proses memberi tuntunan dan pedoman serta jalan hidup yang harus dilalui dan dihindari oleh manusia agar mereka mendapat petunjuk dan terhidar dari kesesatan.

b. Proses mengubah dan memperbaiki keadaan seseorang atau masyarakat dari yang tidak baik kepada yang baik, dari masyarakat jahili menjadi masyarakat Islami.

c. Memberikan penghargaan akan sesuatu nilai agama yang didakwahkan itu sehingga dirasakan oleh seseorang atau masyarakat suatu kebutuhan yang vital dalam kehidupannya.

11 Al-Alusi, Al- Fadhl Syihab al-Din al-Sayyid Mahmud, Ruh al-Ma'ini fi Tafsir alQur'an al-Azhim wa al-Sab' al-Hasani, Juz IV, (Beirut: Dâr al-Fikr, 1398 H/1978).hlm. 21

12 Muhammad al-Bahi Al Khulli Tazkirah al-Du'ah, (Mesir: Dar al-Kitab al-'Arabi, 1952) hlm. 27

13 Mochtar Husein, Dakwah Masa Kini, (Ujung Pandang: Nuhiyah, 1986) hlm.2

${ }^{14}$ Abu Bakar Zakaria, al-Da'wah ila al-Islam, (Mesir: Dâr al-'Urulah, tth.) hlm. 8 
Dalam pelaksanaan dakwah digunakan media sebagai sarananya. Media dakwah merupakan salah satu unsur penting yang harus diperhatikan dalam aktivitas dakwah. Media itu sendiri memiliki relativitas yang sangat bergantung dengan situasi dan kondisi yang dihadapi. Hamzah Ya'qub dalam Aziz (2012) membagi wasilah (media) dakwah menjadi lima, yaitu lisan, tulisan, lukisan, audio visual, dan akhlak. ${ }^{15}$

1. Lisan, yaitu wasilah dakwah yang paling sederhana yang menggunakan lidah dan suara. Dakwah dengan wasilah ini dapat berbentuk pidato, ceramah, kuliah, bimbingan, penyuluhan, dan sebagainya.

2. Tulisan, yaitu dakwah dengan menggunakan media tulis (cetak), seperti buku, majalah, surat kabar, dan spanduk.

3. Lukisan, bisa berupa gambar atau karikatur.

4. Audio visual, yaitu alat dakwah yang merangsang indera pendengaran atau penglihatan. Misalnya, televisi, film, slide, internet, dan sebagainya.

5. Akhlak, yaitu perbuatan-perbuatan nyata yang mencerminkan ajaran Islam yang dapat dinikmati dan didengarkan oleh mad'u. $^{\prime}$

Dari media dakwah di atas dapat diketahui bahwa keberadaannya mempunyai kelebihan dan kelemahan masing-masing. Penelitian ini berusaha mengungkap dakwah yang dilakukan oleh Nabi Muhammad SAW melalui tulisan, yang kemudian dikenal sebagai dakwah bi al-qalam atau dakwah korespondensi. Kata "korespondensi" biasa diartikan sebagai "surat" yaitu: kertas atau bahan lain seperti kain atau sesuatu yang lainnya yang mempunyai fungsi untuk ditulisi dengan berbagai isi yang dituliskan dengan maksud dan fungsi di dalamnya. ${ }^{16}$

Surat adalah alat komunikasi yang mempergunakan bahasa tulisan di atas selembar kertas yang sangat erat hubungannya dengan kehidupan manusia. Sejak zaman dahulu hingga zaman serba modern ini, manusia tidak dapat melepaskan dirinya dari kepentingan manusia lainnya baik yang berada di sekitarnya maupun di tempat yang berjauhan. ${ }^{17}$ Pengertian surat tersebut bersifat umum dan berlaku untuk berbagai keperluan atau kepentingan tergantung pada maksud dan tujuan masing-masing pengirim surat.

Zaman dahulu bentuk surat sangat sederhana. Penulisan, bahan atau cara mengirimkannya pun juga sangat sederhana. Dahulu orang menuliskan isi surat dengan mempergunakan alat sederhana seperti

15 Moh Ali Azis, Ilmu Dakwah, (Jakarta: Kencana, 2012) hlm. 120

16 Departemen Pendidikan dan Kebudayaan, Kamus Besar Bahasa Indonesia, (Jakarta: Balai Pustaka, 1990) hlm. 873

17 Heni Subagyo, Surat-Menyurat Lengkap, (Surabaya: Amelia, 1997) hlm. 2 
misalnya dengan mempergunakan bulu ayam, bulu burung atau sejenisnya. Bahkan ada juga yang mempergunakan ukiran yang dipahatkan pada kulit atau daun-daunan. Cara mengirimkannya pun juga sangat sederhana. Mereka mempergunakan tenaga manusia untuk mengirimkan surat. Caranya cukup dengan hanya berjalan kaki atau bahkan berlari walaupun jarak yang harus ditempuhnya cukup jauh.

Bagi masyarakat awam, istilah surat bukanlah sesuatu yang baru (asing). Surat digunakan oleh seseorang sebagai sarana penyampaian pesan tertulis untuk berbagai kepentingan, baik pribadi, kedinasan maupun bisnis dari seseorang kepada orang atau pihak lain. Seiring dengan perkembangan teknologi informasi dan komunikasi yang begitu pesat, penulisan dan penyampaian suatu pesan dari satu pihak kepada pihak lain dapat dilakukan bukan saja dengan kertas, tetapi juga melalui surat elektronik (electronic mail / e-mail). Bahan yang digunakan dalam menulis surat biasanya adalah kertas tulis baik yang bergaris maupun kertas polos. Surat merupakan salah satu media komunikasi konvensional yang sangat populer di kalangan masyarakat untuk menyampaikan pesan-pesan bisnis dan non-bisnis kepada pihak lain.18

Akan tetapi, karena e-mail adalah sesuatu bentuk media komunikasi yang dilakukan melalui media komputer dan jaringan telepon, si penerima surat juga harus memiliki e-mail yang jelas dan seperangkat komputer serta jaringan telepon yang dapat digunakan untuk browsing di internet, termasuk mengirim e-mail. Meskipun sekarang ini sudah muncul adanya surat elektronik (e-mail), bukan berarti surat yang ditulis melalui kertas menjadi tidak laku atau tidak digunakan lagi. Bagaimanapun juga, keberadaan surat elektronik rasanya sulit untuk menggeser atau menggantikan keberadaan surat kertas yang sudah sejak dulu kala dimanfaatkan oleh masyarakat pada umunya sebagai sarana berkomunikasi yang murah meriah. ${ }^{19}$ Paling tidak keberadaan surat elektronik dalam kehidupan modern ini dapat dianggap sebagai salah satu alternatif komunikasi yang dapat melengkapi surat kertas yang telah ada sebelumnya. hlm. 178

18 Djoko Purwanto, Djoko, Komunikasi Bisnis, Edisi Ke-4, (Jakarta: Erlangga, 2006).

${ }^{19}$ Djoko Purwanto, Komunikasi ... hlm. 179-180 


\section{Latarbelakang Dakwah Korespondensi Nabi Muhammad SAW}

Ketika proses penyampaian "nasehat-nasehat yang baik" (mauidhah hasanah), dalam dakwah, terdapat berbagai macam media (wasa'il) yang digunakan. Satu diantaranya ialah dengan media "surat" dan jurnalistik. Surat merupakan sarana komunikasi tertulis untuk menyampaikan informasi, pernyataan, atau pesan kepada pihak lain. Dengan demikian, surat membawa informasi, pernyataan, atau pesan dari penulis surat kepada seseorang. ${ }^{20}$

Penyampaian nasehat atau pun pelajaran yang baik itu bisa dalam bentuk lisan (verbal advice) dan tulisan (written advice). ${ }^{21}$ Semuanya mengandung nilai-nilai dakwah metode "Mauidhah Hasanah" yang terkandung di dalam Al-Qur'an surat al-Nahl ayat 125. Dakwah melalui media surat inilah yang dipahami sebagai dakwah secara tertulis. ${ }^{22}$ Pada sejarah Islam periode awal, penggunaan surat sebagai media dakwah mempunyai dua prosedur penyampaian.

Pertama, surat dakwah yang bersifat "open letter" atau surat terbuka. ${ }^{23}$ Fakta historis menyebut, penggunaan open letter ini oleh Nabi Muhammad SAW. biasa ditujukan kepada raja ataupun penguasa-penguasa negara lain yang substansi suratnya berisi pesan teologis berupa ajakan kepada Islam dan pengesaan Allah SWT,sebagai sarana yang berperan untuk melapangkan jalan dakwah,dan rasulullah SAW. ingin membuktikan bahwa risalah Islam adalah alamiah untuk seluruh umat manusia.. ${ }^{24}$ Ibnu Hisyam dalam sirah nabawiyah-nya memberikan contoh terkait penggunaan surat sebagai media dakwah ini, ketika raja Najasyi (negus) pemimpin bangsa Abyssinia Ethiopia sekarang mendapat ajakan memeluk Islam dari Rasulullah SAW. ${ }^{25}$ Media dakwah yang digunakan saat itu ialah surat yang bersifat open letter. Efiktifitasnya pun dapat dilihat dengan sambutan baik sang raja atas ajakan kepada agama tauhid tersebut.

Raja Najasyi penguasa Habasyah (Ethiopia sekarang) memeluk agama Islam dari ajakan Rasulullah SAW. melalui surat dakwahnya.

20 Wahyu ilaihi dan Harjani Hefni, Komunikasi Dakwah, (Bandung: PT. Remaja Rosda Karya, 2010) hlm. 194

21 Wahyu Ilaihi, Komunikasi ..., hlm. 57

22 Moh Ali Aziz, Ilmu Dakwah, hlm. 136

${ }^{23}$ Heny Subagyo, Surat..., hlm. 101

24 Wahyu Ilaihi, Komunikasi..., hlm. 64

25 Abdul Malik Ibnu Hisyam, Shirah Nabawiyah, (Beirut: Dar al Kutub Al-Ilmiah, 1971) hlm. 556 
Sambutan baik dari Raja Mesir yaitu Muqouqis meski tidak memeluk agama Islam, ia member hadiah kepada Rasulullah SAW. Demikian juga Raja Heraclius Penguasa Romawi Timur yang sangat tertarik ketika mendengar bahwa Islam adalah suatu risalah yang pasti benar, meski ia juga tidak memeluk agama Islam. ${ }^{26}$

Kedua, surat dakwah yang bersifat "sealed letter" atau surat tertutup. ${ }^{27}$ Media dakwah surat tertutup seperti ini pada praktek yang dilakukan Nabi Muhammad SAW. lebih bersifat dakwah secara sembunyisembunyi. Hal ini dapat dilihat pasca penaklukan kota Makkah (Fathu Makkah), melalui media surat yang bersifat "sealed letter" inilah Nabi Muhammad SAW.menyampaikan pesan-pesan dakwahnya kepada penduduk Makkah yang mayoritas belum memeluk Islam.Hal ini juga menunjukkan bahwa penggunaan surat sebagai media dakwah memiliki efektifitas yang signifikan dalam dinamika dakwah.

Dalam Islam, tulisan merupakan media awal yang sama usianya dengan media tatap muka. Lihat saja Nabi Muhammad SAW. dalam melakukan aktivitas dakwahnya menggunakan berbagai media untuk penyebaran pesan-pesan agama Islam tersebut kepada sasaran. Salah satu media yang digunakan Nabi SAW. dalam aktivitas dakwah adalah surat. Nabi Muhammad SAW. ternyata memandang perlu untuk berkirim surat kepada para penguasa wilayah di berbagai daerah luar Jazirah Arab untuk menyampaikan ajaran Allah SWT yang diturunkan kepada beliau. Betapa tidak, media dakwah tidak menutup adanya kemungkinan yang baik untuk menyampaikan ajaran Islam. Setidak-tidaknya melalui surat inilah Nabi SAW. kemudian menyampaikan dakwahnya mengajak para pembesar untuk masuk agama Islam.28

Paling tidak dalam penggunaan surat sebagai media dakwah, harus terkandung pesan dakwah yang pokok. Yaitu, yang pertama, mengandung pesan teologis berupa ajakan dalam mengesakan Allah SWT, Tuhan semesta alam. Ini merupakan salah satu aspek urgen dalam substansi surat dakwah. Kedua, adanya ajakan santun memeluk agama Islam kepada mereka yang belum pada jalan-Nya, atau ajakan kembali kepada Islam yang benar bagi mereka yang menyimpang dari jalan-Nya.Dan ketiga, mengandung himbauan agar senantiasa berlaku baik dimuka bumi.

26 Majid Ali Khan, Muhammad SAW. Rasul Terakhir, Penerjemah: Fathul Umam, (Bandung: Pustaka, 1985) hlm. 202-203

${ }^{27}$ Heny Subagyo, Surat ..., hlm. 27

28 Samsul Munir Amin, Rekonstruksi Pemikiran Dakwah Islam, (Jakarta: Amzah, 2008) hlm. 146-47 
Ketigaaspek pesan dalam surat dakwah tersebut sudah sepatutnya disampaikan dengan pola yang sesuai dengan kode etik yang ada.

Dengan demikian, maka Rasulullah SAW. telah merintis sistem jurnalistik di dalam dakwah yang berarti bahwa dakwah dapat dilakukan dengan menggunakan berbagai media yang ada termasuk media tulisan. ${ }^{29}$ Media tulisan inilah yang dipraktekkan Rasulullah SAW. melalui surat dakwahnya kepada para raja yang pada akhirnya dunia mengenal Madinah dengan kebenaran keyakinannya, yaitu agama Islam.

\section{Dakwah Korespondensi Nabi Muhammad SAW}

Menurut ahli Sejarah Islam, Muhammad bin Sa'ad sebagaimana dilansir oleh Ya'cub (1997) ${ }^{30}$, disebutkan dari keseluruhan surat-surat Rasulullah yang pernah ada, tercatat ada sekitar 105 buah surat yang telah ditulis lengkap dengan sanadnya.

Sementara untuk lebih khusus, dalam hal jumlah surat-surat yang pernah disampaikan Rasulullah kepada para penguasa belum dapat dipastikan jumlahnya. Tentunya jumlah surat seruan yang telah dibuat oleh Rasulullah lebih dari lima buah sebagaimana yang telah menjadi tema dalam penyusunan penulisan ini. Ketika muncul gagasan untuk mengirimkan surat-surat seruan yang ditujukan kepada para penguasa itu, situasi yang berlangsung dalam masyarakat Islam di Madinah sangat kondusif. Keadaan seperti itu jelas sangat memungkinkan bagi Rasulullah untuk menyampaikan banyak surat seruan yang ditujukan kepada para pemimpin yang ada di Jazirah Arab maupun wilayah-wilayah lain di luar Jazirah Arab. ${ }^{31}$

Alasan menampilkan lima surat Rasulullah ini dengan pertimbangan bahwa surat-surat tersebut sangat populer dan selalu menjadi salah satu kajian dan bagian dalam studi sejarah Islam permulaan. Adapun surat-

${ }^{29}$ Ali Mustofa Ya'cub, Sejarah dan Metode Dakwah Nabi (Jakarta: Pustaka Firdaus, 1997) hlm. 58

${ }^{30}$ Ali Mustofa Ya'cub, Sejarah..., hlm. 80

31 Sebagai contoh adalah surat seruan Rasulullah yang ditujukan kepada Mundhir bin SAWa, seorang penguasa di Bahrain. Kedudukan Mundhir bin SAWa pada saat itu adalah sebagai Gubernur Wilayah (Prekurator) yang dibawah kekuasaan Kisra Eperwiz, Persia. Rasulullah juga menulis surat yang sama kepada Haudzah bin Ali, seorang penguasa al Yamamah yang terletak di sebalah timur kota Makkah. Surat yang sama jugadisampaikan kepada dua penguasa yang berada diwilayah Oman, yakni Jaifar dan Abdu bin Julandi. Lihat Kholid Sayyid Ali, Surat-surat Nabi Muhammad. Penerjemah H.A. Aziz Salim Basyarahil (Jakarta: Gema Insani Press, 1991), hlm. 57-65. 
surat yang pernah disampaikan oleh Rasulullah kepada para penguasa itu adalah sebagai berikut:

\section{Surat Kepada Kaisar Najasyi}

Surat Dakwah Rasulullah yang disampaikan pertama kali untuk penguasa di luar Jazirah Arab adalah surat yang ditujukan kepada Kaisar Najasyi. Surat seruan untuk masuk Islam ini disampaikan pada tahun ke-5 Hijriyah atau bertepatan dengan tahun 628 Masehi. Kaisar ini adalah seorang pemeluk keyakinan Nasrani (Kristen). Nama lain yang biasa disebut bagi Najasyi pada saat itu adalah dengan sebutan "Ash-Hamah". ${ }^{32}$ Ia adalah seorang kaisar yang berkuasa atas wilayah Habsyah atau Habsyi. ${ }^{33}$ (Al Husaini, 2000: 750). Sebutan ini kemudian berkembang dan populer menjadi nama Abbesinia atau sekarang dikenal sebagai Negara Ethiopia, suatu kawasan yang berada di timur laut benua Afrika.

Ada alasan kuat yang dijadikan sandaran Rasulullah untuk mengirimkan surat seruan kepada penguasa ini. NamaKaisar Najasyi telah sangat dikenal oleh kaum muslimin beberapa tahun sebelum mereka melakukan hijarah ke Madinah. Pada saat kaum Muslimin di Mekkah berada dalam tekanan dan penindasan Kaum Quraish, Rasulullah pernah memerintahkan agar pengikutnya melakukan hijrah ke Habsyi. Bahkan pelaksanaan hijrah ke Habsyi ini berlangsung dua kali.

Kaisar ini dikenal sebagai penguasa yang mempunyai sifat-sifat sangat baik seperti adil, jujur, menghormati dan melindungi tamu serta tidak mudah termakan hasutan. Sifat dan sikap seperti inilah yang ditunjukkannya ketika menerima rombongan kaum Muslimin yang hijrah ke wilayahnya. Dengan demikian sebelum Rasulullah menyampaikan surat, antara umat Islam dengan Kaisar Najasyi telah tercipta hubungan yang sangat baik.

Orang yang dipercayai oleh Rasulullah SAW. untuk menyampaikan surat dakwah untuk masuk Islam kepada Raja Najasyi ini adalah Amru bin Umayyah Ad-Dhamiri. ${ }^{34}$. Adapun isi dari surat dakwah Rasulullah SAW. kepada Raja Najasyi adalah sebagai berikut:

\footnotetext{
32 Orang Arab pada saat itu sering menyebut kaisar ini dengan sebutan "An-Najasyi As-Shamah".

33 Al Hamid al Husaini, Membangun Peradaban; Sejarah Muhammad SAW, Sejak Sebelum Diutus Menjadi Nabi (Bandung: Pustaka Hidayah, 2000) hlm. 363-372

34 Ahmad Hatta dkk, The Great Story Of Muhammad SAW., (Jakarta: Maghfirah Pustaka, 2011) hlm.420
} 


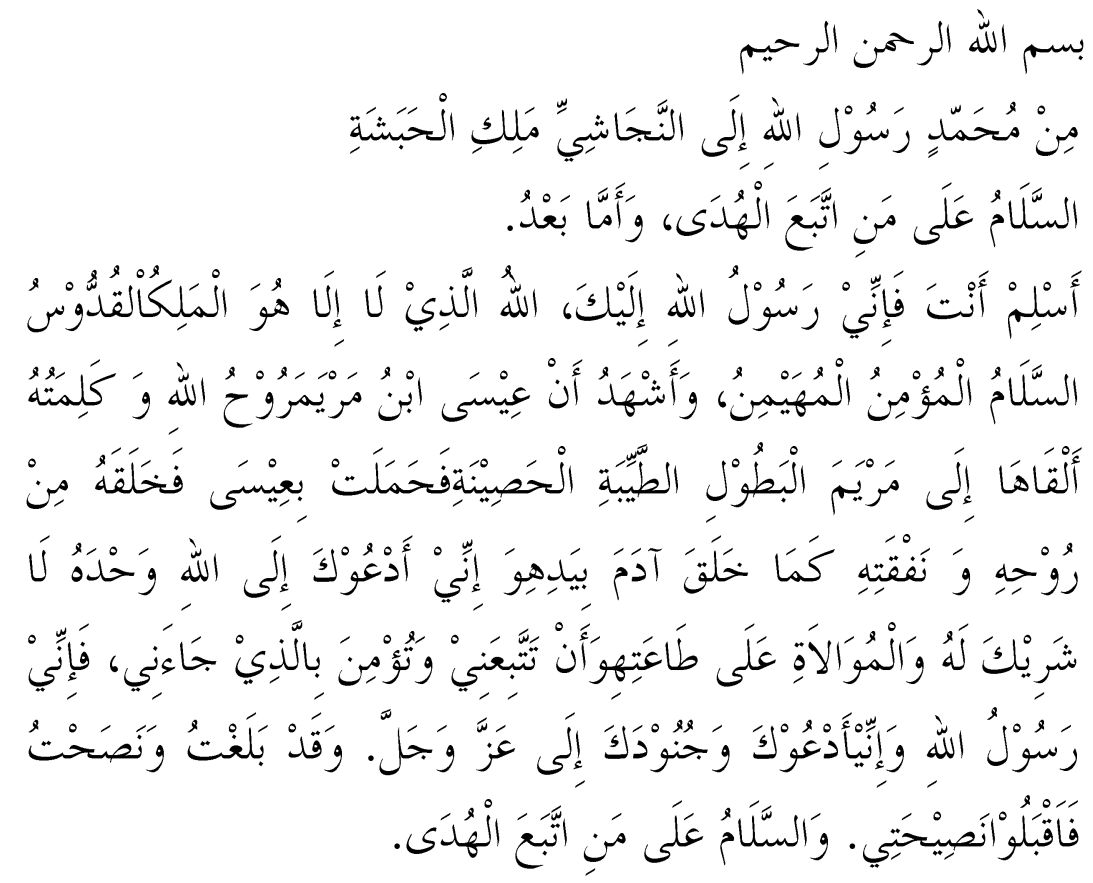

"Dengan nama Allah yang Maha Pemurah lagi Maha Penyayang. Dari Muhammad utusan Allah kepada Najasyi Raja Habasyah, keselamatan bagi yang mengikuti petunjuk.

Amma ba'du: aku memuji Allah padamu yang tidak ada Tuhan selain Dia, yang Maha Menguasai, Maha Suci, Maha Penyelamat, Maha Pemberi Aman, dan Maha Pembeda. Aku bersaksi bahawa Isa anak Maryam ruh Allah, dan firman-Nya yang diberikan kepada Maryam yang suci lagi perawan, lalu ia hamil dari ruh dan tiupannya, sebagaiman Ia menciptakan Adam dengan tangan-Nya. Aku mengajakmu kepada Allah yang Esa, yang tidak ada sekutu bagi-Nya, mematuhi dengan ketaatan kepadaNya, dan untuk mengikutiku dan mempercayai apa yang aku bawa. Aku Rasulullah, aku mengajakmu dan para pasukanmu kepada Allah yang Maha Perkasa lagi Maha Timggi. Aku telah menyampaikan pesan dan memberi nasihat, maka terimalah nasihatku.keselamatan bagi orang yang mengikuti petunjuk". 35

35 Muhammad bin Sa'ad bin Mani' al-Hasyimi al-Basri al-Ma'rufi bi ibni Saad, Thabaqat al-Khubra, Juz 1, (Beirut-Lebanon, Darul Kutub Ilmiyah, 1990) hlm.15 
Ketika Nabi mengutus dutanya ke Habasyah (Etiopia) sebagian pengungsi muslim masih menetap di sana, sementara yang lain sudah kembali ke Madinah dan memuji keadilan penguasa negeri itu serta kebaikannya atas rakyatnya. Keramahan dan kehalusan yang khas dalam bunyi surat Nabi SAW. kepada penguasa itu disebabkan oleh kesadaran beliau atas kebaikannya. Dalam surat-suratnya yang ditujukan kepada penguasa lain Nabi Muhammad SAW. memperingatkan mereka akan datangnya kemurkaan Ilahi dan mengatakan bahwa bila mereka tidak menyatakan imannya kepada Islam dosa-dosa yang tidak memeluk Islam karena takut akan dicatat sebagai si penguasa. Namun yang demikian itu tidak terdapat dalam surat kepada Negus. ${ }^{36}$

Dalam surat itu terdapat rujukan kepada beberapa sifat utama Allah SWT yang menunjukkan keesaan dan keagungan-Nya. Sesudah itu Nabi SAW. mengemukakan masalah ketuhanan Nabi Isa AS yang merupakan ciptaan pikiran lapuk Gereja dan membantahnya dengan argumen yang disimpulkan dari Al-Qur'anul Karim. Mengenai nabi Isa AS yang dilahirkan tanpa ayah beliau menerangkannya dengan membandingkannya dengan kelahiran Adam dan membuktikan bahwa jika kelahiran tanpa ayah menjadi dalil bagi seseorang menjadi anak tuhan dalil yang sama mestinya juga berlaku bagi Adam padahal umat Kristen tidak memandangnya sebagai tuhan.

\section{Surat Kepada Kaisar Heraklius}

Heraclius adalah kaisar imperium Romawi yang pernah memerintah Bizantium. Ia memimpin pemerintahan yang besar. Bersama pemerintahan Sasaniyah Iran, ia memimpin dunia pada saat itu. Ia menguasai hampir seluruh dari dunia. Ia menguasai daerah-daerah kaya, yang terbentang di tiga benua: benua Eropa, Afrika dan Asia. Ia memerintah Imperium Romawi yang besar, yang ditakuti oleh dunia pada zaman itu. ${ }^{37}$ Ia berasal dari keluarga Yunani asli. Lahir di Kubudisyiyah dan besar di Qirthajinah, ${ }^{38}$ Anak dari seorang penguasa Afrika-Rum (Exarch of Afrika). Tidak ada hal yang menunjukkan dalam memimpin, sampai Phocas "Sang Perampas"

36 Ja'far Subhani, Ar-Risalah: Sejarah Kehidupan Rasulullah SAW, Penerjemah: Muhammad Hasyim dan Meth Kieraha, (Jakarta: Lentera, 2000) hlm. 496

37 Ja'far Subhani, Ar-Risalah...., hlm. 346

38 Kota tua di Afrika, didirikan oleh Fainiqiyun pada 814 SM, di dekat reruntuhannya berdirinya kota Tunisia. 
membunuh penguasa pemerintahan Bizantium yang sah, Maurice, yang merupakan sahabat Kisra Abrawaiz pada tahun $602 \mathrm{M}$.

Persia menggunakan kesempatan ini untuk menyerang imperium Bizantium. Mereka berhasil menaklukkan dan menghinakannnya. Akhirnya Imperium Bizantium yang terkenal itu menghembuskan nafasnya yang terakhir. Kemudian dipanggillah Heraclius dari Qirthajinah. Ia berhasil membunuh Phocas dan menerima kendali pemerintahan pada tahun 610 M. Tahun terjadinya peristiwa ini adalah masa diutusnya Nabi Muhammad SAW. di Jazirah Arab. Negara (Romawi) saat itu berada di antara hidup dan mati, ditimpa kelaparan, wabah penyakit, kemiskinan, dan krisis ekonomi. ${ }^{39}$

Namun kemudian terjadilah perubahan pada tahun $616 \mathrm{M}$ (di tahun inilah Al-Qur'an memberitakan kemenangan Romawi dalam beberapa tahun kemudian). Pada tahun itu Romawi berubah dari kerajaan yang hina dina menjadi kerajaan yang terhormat dan kaya. Pemimpinnya bersemangat dan pikirannya cerdas. Semangatnya terus berkobar sehingga bergerak mendekati pusat wilayah imperium Iran. Negara dan kehormatan rakyat pun terlindungi.40

Heraclius kembali dalam kemegahan seperti semula. Sampai serangan Islam menyebabkan hilangnya kekuasaan dan berakhirnya pemerintahan Bizantium dari Asia dan Afrika. Bagaimanapun juga, Romawi adalah pemerintahan terbesar pada masanya, yang tidak tertandingi keluasan kekuasaannya, kekuatan armada perangnya, dan kemegahan kotanya, kecuali oleh Imperium Iran (Kisra II). Heraclius meninggal pada tahun $641 \mathrm{M}$ di Konstantinopel dan dimakamkan di sana. ${ }^{41}$

Mengenai surat dakwah dari Nabi SAW. yang mengajak kepada agama tauhid. Surat ini diarahkan kepada Heraclius, penguasa Romawi. ${ }^{42}$ Nabi SAW. mengirim surat tentang Islam dan kesejahteraan kepada Heraclius yang dibawa oleh seorang sahabat mulia, Dihyah bin Khalifah Al-

39 Ja'far Subhani, Ar-Risalah...., hlm. 348

40 Pada tahun $626 \mathrm{M}$ ini, terjadilah perang Badar yang besar. Sehingga kemenangan kaum muslimin atas kaum musyrik Makkah itu bertepatan dengan kemenangan Romawi Ahli Kitab atas musuhnya, kaum Persia penyembah berhala. Benarlah berita Al-Qur'an tentang kemenangan Romawi yang akan terjadi beberapa tahun kemudian (kurang dari sepuluh tahun).

${ }^{41}$ Ja'far Subhani, Ar-Risalah...., hlm. 354

42 Syaikh Uhaimid Muhammad Al-Uqaili, Surat-Surat Nabi kepada Para Raja dan Panglima Perang, Penerjemah: Wafi Marzuqi Ammar, (Surabaya: Putaka Yassir, 2011) hlm.124 
Kalbiy R.A.43 Ia menyerahkannya kepada penguasa Bushra dan mengantarnya kepada Heraclius. Bunyi teksnya adalah sebagai berikut:

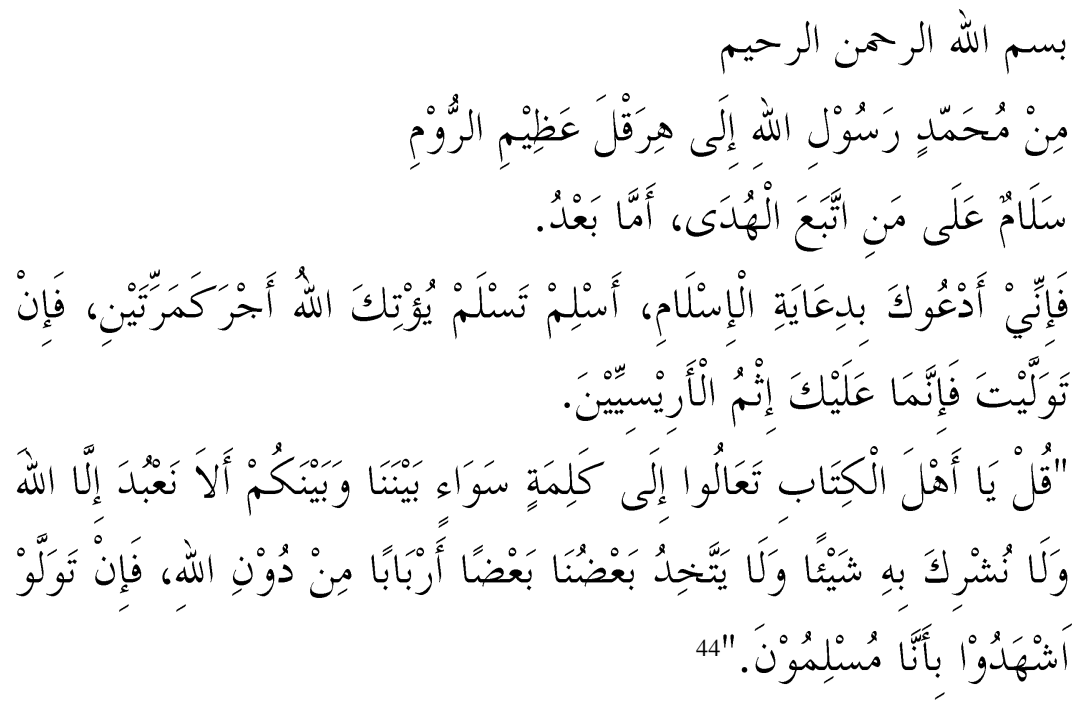

"Dengan nama Allah yang Maha Pemurah lagi Maha Penyayang Dari Muhammad hamba Allah dan utusan-Nya, kepada Heraclius Raja Romawi. Keselamatan bagi yang mengikuti petunjuk.Amma ba'du:

43 Sahabat ini berasal dari suku Khazraj. Mereka adalah para penolong Rasulullah SAW. dan penolong dakwah beliau di Madinah. Dihyah r.a termasuk sahabat yang masuk Islam pada masa-masa awal. Dia menyaksikan seluruh peristiwa peperangan di masa awal Islam, seperti perang Badar. Karena itulah dia termasuk alumni madrasah Rasulullah SAW. di Madinah. Dihyah diistimewakan dengan beberapa sifat mulia yang dicari-cari Rasulullah SAW. untuk dijadikan utusannya. Salah satu sifat Dihyah adalah dia sangat mirip dengan Jibril dalam ketampanannya. Dan diantara sifat para duta Rasulullah SAW. adalah sempurna akalnya, cepat tanggap, sangat cerdas, tak diremehkan di mata orang-orang atau dipicingkan oleh pandangan mereka. Baca: Syaikh Uhaimid Muhammad Al-Uqaili, SuratSurat Nabi kepada Para Raja dan Panglima Perang, Penerjemah: Wafi Marzuqi Ammar, hlm. 125.

${ }^{44} \mathrm{Al}-\mathrm{Imam}$ Abi 'Abdillah Muhammad Ibnu Ismail Ibnu Ibrahim Ibnu Mughirah Ibnu Bardazabah al-bukhari al-Ja'fiyyi, Shahih Bukhari, Juz 1, (Beirut-Libanon: Darrul kutub Ilmiyah), 1992. hlm. 7. Baca juga teks Surat Nabi SAW. kepada Raja Heraclius ini, oleh KH. Moenawar Chalil, Kelengkapan Tarikh Nabi Muhammad SAW. II, (Jakarta: Gema Insani Press), 2001. hlm. 391. Teks asli lihat Abul Hasan Ali Al-Hasan An-Nadwi, Shirah Nabawiyah,Sejarah Lengkap Nabi Muhammad SAW, Cet. ke-6, Penerjemah: M. Halabi Hamdi dkk., (Yogyakarta: Darul Manar), 2011, hlm. 350. 
Sesungguhnya aku mengajakmu masuk Islam. Maka, masuklah Islam maka kau akan selamat, dan kau akan diberikan oleh Allah pahala dua kali lipat. Jika kau menolak, maka kau menanggung dosa orang-orang Arisiyin (Arison).

"Katakanlah: Hai ahli kitab, marilah (berpegang) kepada suatu kalimat (ketetapan) yang tidak ada perselisihan antara kami dan kamu, bahwa tidak kita sembah kecuali Allah dan tidak kita persekutukan dia dengan sesuatupun dan tidak (pula) sebagian kita menjadikan sebagian yang lain sebagai Tuhan selain Allah". jika mereka berpaling Maka Katakanlah kepada mereka: "Saksikanlah, bahwa kami adalah orang-orang yang berserah diri (kepada Allah)".

Heraclius hendak memastikan tentang perihal Nabi SAW. Ia mencari orang yang akan memberitahu tentang hal tersebut. Kebetulan ia menemukan Abu Sufyan di Ghazzah yang datang untuk berdagang. Ia lalu menyuruhnya untuk menghadap. Pertanyaan-pertanyaan yang diajukan Heraclius adalah pertanyaan seorang yang cerdas dan berpengalaman tentang sejarah agama-agama, khususnya tentang Nabi-nabi dan sejarah hidup mereka; tentang sejarah umat yangbersama mereka, dan sunnah Allah pada mereka. Abu Sufyan membenarkan keadaan bangsa Arab klasik daripada melebihkan orang-orang tersebut

Lalu Heraclius berkata pada penerjemah: katakan padanya: " $A k u$ telah menanyakan tentang nasabnya, dan kau menjawab bahwa ia mempunyai nasab yang baik". Demikianlah para Rasul, mereka diutus dari nasab yang baik di antara kaumnya. Aku telah bertanya kepadamu, apakah salah seorang dari kalian telah mengatakan hal (risalah) ini? Kau menjawab tidak. Aku katakan, seandainya seseorang telah mengatakan perkataan ini sebelumnya, maka aku katakan bahwa ia mengikuti perkataan orang sebelumnya."

"Aku bertanya kepadamu, apakah kalian menuduhnya sebagai pendusta sebelum ia mengatakan (risalah) yang ia katakan? Kau menjawab tidak. Aku tahu bahwa ia tidak akan pernah membohongi manusia, apalagi mendustai Allah. Aku bertanya kepadamu, apakah yang mengikutinya adalah orang-orang terhormat ataukah orang-orang dhu'afa? Kau menjawab, yang mengikutinya adalah orang-orang dhu'afa. Mereka itulah pengikut para Rasul."

"Aku bertanya kepadamu, apakah mereka bertambah ataukah berkurang? Kau menjawab bahwa mereka bertambah. Demikianlah keimanan itu terjadi sampai ia sempurna." 
"Aku bertanya kepadamu, apakah pengikutnya ada yang murtad karena benci agamanya setelah memeluknya? Kau menjawab tidak. Demikianlah keimanan itu telah menyatu dengan hati".

"Aku bertanya kepadamu, apakah ia pernah berbohong? Kau menjawab tidak. Demikianlah, para rasul memang tidak pernah berbohong."

"Aku bertanya kepadamu, apa yang ia perintahkan kepada kalian? Kau menyebut bahwa ia memerintahkan kalian untuk menyembah Allah, tidak menyekutukannya dengan suatu apa pun, melarang kalian untuk menyembah berhala, dan menyuruh kalian untuk mendirikan shalat, bersedekah, dan menjaga kehormatan. Jika apa yang kau katakan itu benar maka ia akan menguasai hingga tempat kedua kakiku iniberdiri. Aku memang telah mengetahui bahwa ia akan keluar diutus, akan tetapi aku tidak mengira jika ia dari kaum kalian. Jika aku tahu, aku akan berusaha sekuat tenaga untuk menemuinya. Jika saja aku berada di sisinya, akan aku basuh kedua kakinya (Asy-Syafi'i, 1993: 102 -103).

Heraclius kemudian memanggil para pembesar Romawi ke ruang besar, dan menyuruh menutup pintunya. Kemudian ia naik dan berkata: "Wahai rakyat Romawi! Bagaimana jika kalian dalam kebahagiaan dan petunjuk, kerajaan kalian tetap kokoh, dan berbaiat pada Nabi ini!" Mereka segera berlarian dan berebutan menuju pintu, tapi mereka mendapatkannya setelah ditutup. Saat Heraclius melihat mereka berlarian, timbullah penyesalan atas keimanannya. Ia lalu berkata, "Kembalilah kalian padaku. Aku mengatakan perkataan tadi hanya untuk menguji keteguhan agama kalian; dan aku telah melihatnya." Mereka pun bersujud pada Heraclius dan meridhainya.

Demikianlah, Raja Heraclius akhirnya mengesampingkan hidayah. Terjadilah peperangan dan pertempuran antara dia dan kaum muslimin pada masa kekhalifahan Abu Bakar dan Umar. Pada masa itulah kerajaan dan kekuasaannya hancur, kalah dengan umat Islam. ${ }^{45}$

\section{Surat Kepada Kisra Eperwiz}

Sepucuk surat juga dikirimkan Rasulullah SAW. kepada Kaisar Persia yang bergelar Kisra. Isinya serupa dengan surat-surat yang beliau kirimkan kepada para Raja dan Kaisar di berbagai belahan dunia. ${ }^{46}$ Surat yang

45 Abul Hasan Ali Al-Hasan An-Nadwi,, Shirah Nabawiyah, Sejarah Lengkap Nabi Muhammad SAW, Cet. ke-6, Penerjemah: M. Halabi Hamdi dkk., (Yogyakarta: Darul Manar, 2011) hlm. 362

${ }^{46}$ Syaikh Uhaimid Muhammad Al-Uqaili, Surat-Surat..., hlm. 424 
dikirimkan kepada Kisra Abrawaiz, dibawa oleh sahabat Rasulullah SAW. Abdullah bin Huzafah as-Sahmi. ${ }^{47}$ Bunyi surat tersebut sebagai berikut:

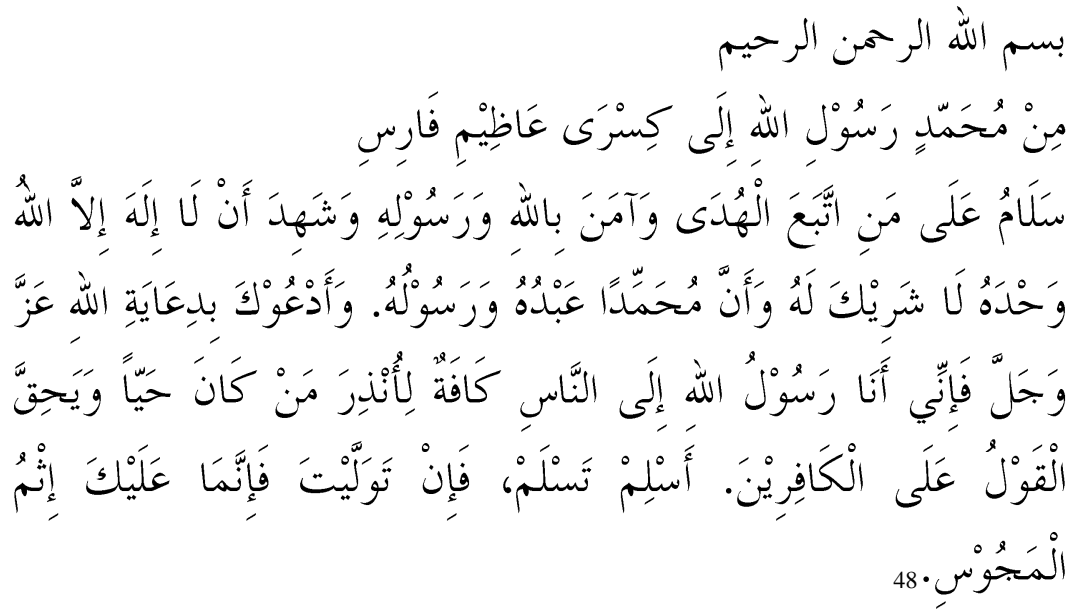

"Dengan nama Allah yang Maha Pemurah lagi Maha Penyayang. Dari Muhammad Rasulullah kepada Kisra Raja Persia.

Keselamatan bagi yang mengikuti petunjuk, yang beriman kepada Allah dan Rasul-Nya, dan bersaksi bahwa tidak ada Tuhan selain Allah dan aku adalah utusan Allah kepada umat seluruh manusia, untuk memberi periingatan bagi siapayang hidup dan supaya pastilah azab terhadap orang-orang kafir. Masuklah Islam maka kau akan selamat, dan jika kau mengabaikannya makaatasmu dosa orang-orang Majusi".

47 Moenawar Chalil, Kelengkapan Tarikh Nabi Muhammad SAW. II,(Jakarta: Gema Insani Press), 2001.hlm. 394.Abdullah bin Huzafah as-Sahmi merupakan utusan Nabi Muhammad SAW. kepada Kaisar Persia untuk menyampaikan surat dari Nabi Muhammad SAW. yang mengajak memeluk agama Islam. Ia juga dikenal sebagai salah satu tawanan perang dari Heraclius dari Kekaisaran Romawi Timur. Atas keimanannya yang kuat terhadap Islam dan dapat melewati setiap godaan yang diberikan oleh Kaisar Heraclius, Seluruh tawanan perang Muslim dibebaskan tanpa syarat.

${ }^{48} \mathrm{Al}$-Imam Abi 'Abdillah Muhammad Ibnu Ismail Ibnu Ibrahim Ibnu Mughirah Ibnu Bardazabah al-bukhari al-Ja'fiyyi, Shahih Bukhari, Juz 5, (Beirut-Libanon: Darrul kutub Ilmiyah), 1992. hlm. 274. lihat musnad ahmad I : 243-305. Baca juga teks Surat Nabi SAW. kepada Raja Heraclius ini, oleh Moenawar Chalil, Op.Cit., hlm. 395. Teks asli lihat Abul Hasan Ali Al-Hasan An-Nadwi, Shirah Nabawiyah, Sejarah Lengkap Nabi Muhammad SAW, Cet. ke-6, Penerjemah: M. Halabi Hamdi dkk., (Yogyakarta: Darul Manar), 2011., hlm. 351. 
Ketika surat tersebut sampai pada Kisra Abrawaiz, ia membacanya lalu merobek surat tersebut sambil berkata: "Ia menulis surat ini kepadaku, padahal ia adalah hambaku?" kabar itu pun sampai pada Rasulullah SAW. Beliau lalu bersabda: "Allah akan merobek kerajaannya.".49

Adapun Kisra Badzan, penguasa Yaman, mengutus Babawaih. Dan Babawaih berkata pada Rasulullah SAW.: "Raja Kisra telah menulis surat kepada Raja badzan dan memerintahkannya agar mengirim utusan kepadamu akan hadir (padanya) bersamamu. Ia mengutusku kepadamu agar kamu mau berangkat bersamaku." Lalu Rasulullah SAW. memberitahukan bahwa Allah SWT akan memberikan kekuasaan Kisra pada anaknya, Syiruwaih, dan membunuhnya. ${ }^{50}$ Semua yang dikatakan Rasulullah SAW. benar-benar menjadi kenyataan. Akhirnya yang menguasai singgasana Kisra adalah anaknya, Qubadz, yang dijuluki dengan nama Syiruwaih. Kisra dibunuh dengan hina pada tahun 628 M. Setelah kematiannya, kerajaannya terpecah-pecah dan menjadi permainan di tangan anak-anak keluarga istana.

Syiruwaih hanya hidup enam bulan saja dalam kurun empat tahun, singgasananya digantikan oleh sepuluh raja. Tampak pemerintahan tercabut hingga orang-orang berkumpul dan menunjuk yazdajir sebagai raja terakhir Bani Sasan. Dialah orang yang menghadapi penyerangan tentara Islam yang menyebabkan runtuhya pemerintahan Sasaniyah yang berjaya lebih dari empat abad lamanya musnah secara keseluruhan. ${ }^{51}$ Setelah itu tidak pernah ada lagi pemerintahan Sasaniyah, dan nyatalah dengan itu berita yang diungkap oleh Rasulullah SAW. dengan sabdanya: "Jika Kisra hancur, maka tidak ada Kisra setelahnya." 52

Allah SWT memberi kuasa kepada kaum muslimin untuk menguasai Iran dan memberi petunjuk penduduknya sehingga masuk Islam. Dari mereka lahir banyak Imam dalam ilmu dan agama, para genius Islam, dan cendekiawan muslim. Benarlah apa yang disabdakan oleh rasulullah SAW, "Seandainya ilmu itu didapat dengan harta kekayaan maka akan didapat oleh orang-orang dari Persia." 53

49 Al-Imam Syihabuddin Abi Al-'Abbas Ahmad Ibn Muhammad Asy-Syafi'I,, Irsyaad Asy-Syaari Syarah Shahih Al-Bukhariy, Juz 6, (Beirut-Libanon: Darrul kutub Ilmiyah, 1993) hlm. 397

50 Abi Ja'far Muhammad Bin Jarir Ath-Tabari,, Taarikh Ath-Tabariy, Juz 3, (BeirutLebanon: Darrul Kutub Ilmiyah, 1991) hlm. 90-91

51 Abul Hasan Ali Al-Hasan An-Nadwi,, Shirah..., hlm. 2236-2237

52 Imam Abi al-Husein Muslim Bin al-Hajjaj al-Qusahiry An-Naisaburi,, Shahih Muslim, Juz 4, (Beirut-Lebanon: Darrul Kutub Ilmiyah, 1992) hlm. 87

53 Muhammad Abdul Salam Abdul Syafi'i,, Musnad Imam Ahmad Bin Hanbal, Juz 3, (Beirut-Lebanon: Darrul Kutub Ilmiyah, 1993) hlm. 363 


\section{Surat Kepada Al Muqauqis}

Nabi SAW. menulis surat kepada Juraij bin Matta yang bergelar Muqouqis, Raja Mesir dan Iskandaria. Surat ini dibawa Hathib bin Balta'ah, adalah pengendara yang berani dan terampil. Ia salah satu dari enam orang yang diutus membawa surat dakwah Nabi SAW. kepada para penguasa dunia. Isi suratnya dapat digambarkan sebagai berikut;

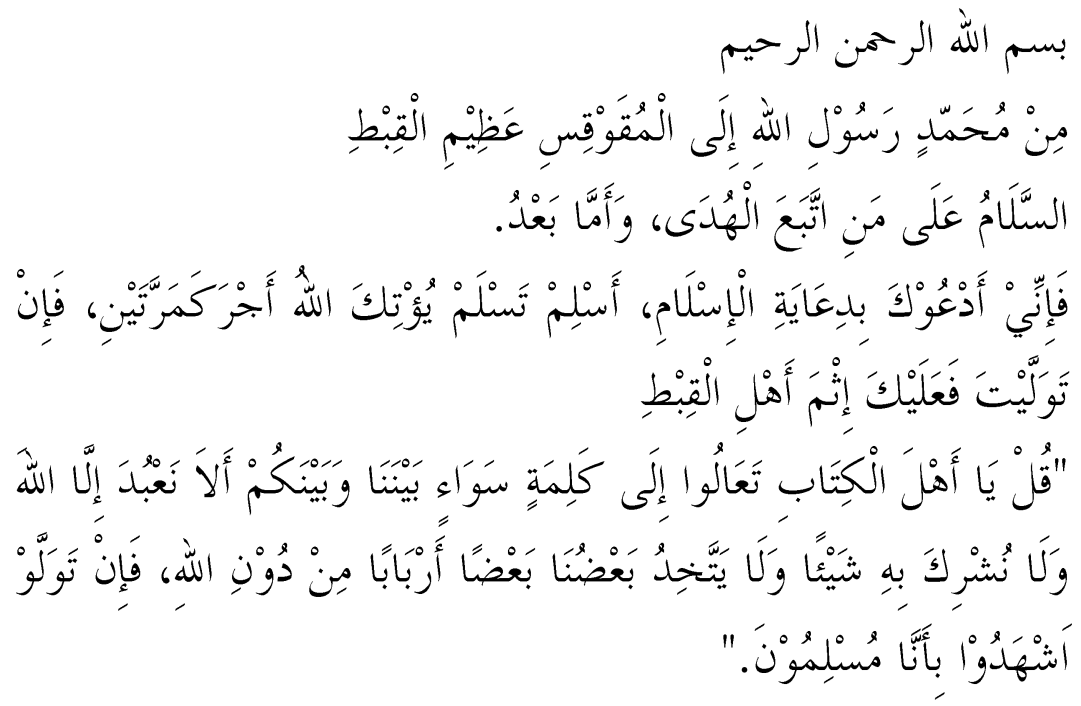

"Dengan nama Allah yang Maha Pengasih lagi Maha Penyayang. Dari Muhammad hamba Allah dan utusan-Nya kepada Muqouqis Raja Qibthi. Keselamatan bagi orang yang mengikuti petunjuk.Amma ba'du:

Aku mengajakmu dengan ajakan Islam. Masuklah Islam maka engkau akan selamat. Masuklah Islam maka engkau akan diberikan Allah pahala dua kali. Jika kau menolak maka atasmu dosa penduduk Qibthi.

Katakanlah: "Hai ahli kitab, marilah (berpegang) kepada suatu kalimat (ketetapan) yang tidak ada perselisihan antara kami dan kamu, bahwa tidak kita sembah kecuali Allah dan tidak kita persekutukan dia dengan sesuatupun dan tidak (pula) sebagian kita menjadikan sebagian yang lain sebagai Tuhan selain Allah". 
jika mereka berpaling Maka Katakanlah kepada mereka: "Saksikanlah, bahwa kami adalah orang-orang yang berserah diri (kepada Allah)".54

Duta Nabi SAW. yang berangkat ke Mesir untuk menyampaikan surat Nabi Muhammad SAW mendengar bahwa sang penguasa tinggal di istana agung di Alexandria. Kemudian dia berangkat ke Alexandria dan memasuki istana Muqouqis dengan perahu. Hatib dijamu oleh raja. Raja membuka surat yang dibawanya, membacanya, dan merenungkan isinya sejenak. Lalu ia mengangkat kepalanya dan mengatakan kepada duta Islam itu, "Bila Muhammad benar-benar Nabi Allah, mengapa musuh-musuhnya dapat mengusirnya dari kampung halamannya dan mengapa ia harus tinggal di Madinah? Mengapa ia tidak mengutuk saja mereka agar dihancurkan Allah?"

Duta yang cerdas dan bijaksana itu menjawab, "Nabi Isa adalah Nabi Allah dan Anda pun mengakuinya. Mengapa ia tidak mengutuk Bani Israil ketika mereka berkomplot untuk membunuhnya supaya Allah menghancurkan mereka?" Penguasa itu yang tidak mengira akan menerima jawaban demikian mengalah pada logika yang kuat sang duta seraya memujinya, "Hebat! Anda adalah orang bijaksana. Anda membawa risalah dari orang bijaksana lagi sempurna." 55

Hatib merasa dihargai dengan jamuan yang ramah oleh penguasa Mesir. Maka ia pun mengajaknya memeluk Islam, "Sebelum Anda seseorang (Fir'aun) memerintah negeri itu. Ia menzalimi rakyat dalam waktu yang lama. Allah SWT menghancurkannya supaya riwayatnya menjadi pelajaran bagi Anda. Namun Anda harus berusaha keras supaya hidup Anda tidak akan menjadi peringatan bagi orang lain seperti dia. Nabi kami mengajak manusia kepada agama suci. Orang Quraisy berkampanye menentangnya. Orang Yahudi juga menentangnya dengan rasa dengki. Kaum yang dekat dengannya adalah umat Kristen. Saya bersumpah demi nyawa saya bahwa tepat sebagaimana Musa bin Imran memberi kabar gembira tentang kenabian Muhammad.

"Saya mengajak Anda kepada agama Islam dan Kitab Suci kami (AlQur'an) sebagaimana Anda telah mengundang pengikut Taurat kepada Injil. Setiap umat yang mendengar seruan Nabi haruslah mengikutinya. Dan sekarang setelah saya menyampaikan seruan Nabi SAW. ke negeri Anda maka pantaslah Anda dan bangsa Mesir mengikuti agamanya. Sekali-kali

\footnotetext{
54 Syaikh Uhaimid Muhammad Al-Uqaili, Surat-Surat..., hlm. 256

55 Ja'far Subhani, Ar-Risalah...., hlm. 494
} 
saya tidak menolak sumpah bahwa saya percaya pada agama Isa. Malah saya harus mengatakan bahwa Anda harus mengikuti agamanya tetapi Anda perlumengetahui bahwa bentuk agama Isa yang sempurna adalah Islam itu sendiri"56

Pertemuan Hatib dengan Muqouqis berakhir tetapi Muqouqis tidak memberikan jawaban yang tegas. Itu sebabnya Hatib harus menetap lebih lama guna mendapatkan jawaban untuk Nabi Muhammad SAW. Suatu hari Muqouqis memanggilnya untuk suatu pertemuan di tempat tersendiri untukmengetahui tentang program dan agama Nabi. Sang duta menjawab, "Ia mengajak orang menyembah kepada AllahYang Esa. Ia menyuruh orang sembahyang lima kali sehari dan puasa di bulan Ramadhan, menunaikan ibadah haji danmenepati janji, juga tidak boleh makan bangkai dan meminum darah..." Hatib mengakhiri ucapannya dengan menjelaskan sifatsifat mulia Nabi Muhammad SAW.

Penguasa Mesir itu berkata kepadanya, "Inilah tanda-tanda kenabian. Saya tahu bahwa nabi terakhir akan muncul. Tetapi saya pikir ia akan muncul di Suriah yang menjadi pusat kemunculan para nabi dan bukan di Hijaz. Tetapi wahai duta Muhammad! Anda harus tahu bahwa bila saya memeluk Islam rakyat Mesir tak akan bekerja sama dengan saya. Saya harap kekuasaan Nabi ini akan mencapai Mesir. Para sahabatnya akan datang ke negeri kami dan mencapai kemenangan atas kekuatan negeri ini dan kepercayaaan palsu. Dan aku menginginkan Anda merahasiakan percakapan ini. Tak seorang Mesir pun boleh tahu tentang ini." 57

\section{Surat Kepada Harits Al Ghissani}

Seperti halnya Al Muqauqis, Harits Al Ghissani adalah seorang wali negara Syam (sekarang negara Suriah). Wilayah ini juga menjadi bagian dari kekuasaan imperium Romawi Byzantium. Sebagai wali negara (prekurator), Harits Al Ghissani berkedudukan di Damaskus. Surat seruan Rasulullah yang disampaikan kepada Harits Al Ghissani ditulis dengan bahasa yang singkat dan orang yang mendapatkan kepercayan dan tanggung jawab untuk menyampaikannya adalah Abu Syujaa' bin Wahab Al-asadi. ${ }^{58}$ (Mahfudz, t.t : 5).

\footnotetext{
56 Ja'far Subhani, Ar-Risalah...., hlm. 494

57 Ja'far Subhani, Ar-Risalah...., hlm. 495

58 Syekh Ali Mahfudz, Hidayatul Mursyidin (Mesir: Asyhar Syarif, t.th) hlm. 5
} 
Selengkapnya isi surat Rasululah kepada Harits Al Ghissani itu sebagai berikut:

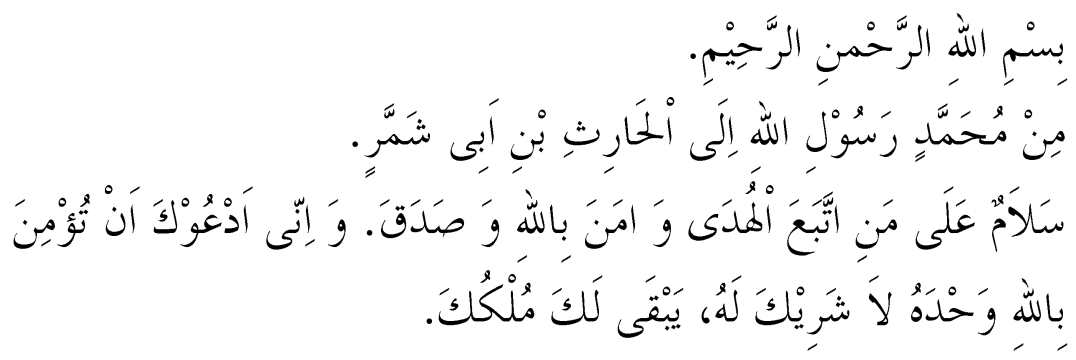

"Dengan menyebut nama Allah Maha Pengasih dan Maha Penyayang. Dari Muhammad Utusan Allah. Kepada Harits bin Abu Syamar.

Salam sejahtera semoga dilimpahkan kepada orang-orang yang mengikuti petunjuk Allah, beriman kepada-Nya dan membenarkan ajaran-Nya.

Sesungguhnya aku mengajak kepada tuan untuk beriman kepada Allah yang Esa dan tidak ada sekutu baginya. Apabila tuan mau menerima ajakan ini maka kekuasaan tuan akan tetap lestari"

Berbeda dengan Al Muqauqis yang menunjukkan sikap penghormatan dan penghargaan atas seruan Rasulullah, sikap yang diperlihatkan Harits Al Ghissani setelah menerima surat ini tidak mencerminkan sikap sebagai pemimpin. Reaksi yang diperlihatkannya sangat jauh dari tatacara dan etika seorang penguasa pada masa itu. Seperti halnya yang dilakukan oleh penguasa Persia (Kisra Eperwiz), Harits Al Ghissani langsung membuang surat seruan itu sambil mempertanyakan apakah ada kekuatan lain selain Kaisar yang dapat mencopot kedudukannya sebagai prekuator. Memang sebagai seorang prekurator, tidak ada orang yang sanggup atau bisa menjatuhkan jabatannya selain dari kaisar Romawi sendiri yakni Kaisar Heraclius.

Terkait dengan sikap Harits dalam menanggapi surat seruan Rasulullah ini didapatkan periwayatan yang tidak bersifat tunggal. Versi pertama, sebagaimana telah diungkapkan didepan, disebutkan bahwa Harits Al Ghissani menunjukkan sikap menolak seruan Rasulullah itu dengan memperlihatkan sikap yang sangat tidak terpuji. Bahkan masih 
dalam versi yang pertama ini, Harits Al Ghissani bersikap seperti Kisra dari Persia yang memerintahkan untuk membunuh utusan Rasulullah.

Namun pada versi yang lain dikisahkan berbeda. Disebutkan bahwa Walinegera yang berkedudukan di Damaskus (Syam atau Suriah) itu menerima dengan baik seruan Rasulullah itu meskipun dilakukan secara rahasia, Harits Al Ghissani dikisahkan secara diam-diam menyatakan diri masuk Islam. Cara diam-diam dan rahasia ini terpaksa dilakukan karena ia takut hal ini akan diketahui oleh orang-orang yang ada di sekitar Kaisar, bahkan ia takut jika hal ini diketahui oleh Kaisar Heraclius sendiri. Perhitungannya, jika tindakan masuk Islam ini diketahui oleh umum maka Harits Al Ghissani akan menghadapi dua risiko yakni; kehilangan jabatan dan mungkin akan dibunuh orang-orang Romawi. Belum bisa dipastikan versi manayang benar. Namun yang jelas antara kaum Muslimin Arab dengan Syam kemudian pernah terlibat dalam sebuah peperangan dahsyat yang dikenal sebagai Perang Mu'tah. Perang ini meletus pada tahun ke-8 Hijriyah atau bertepatan dengan bulan Agustus-September 629 Masehi. Dalam peperangan ini pihak Syam dibantu pasukan Byzantium. ${ }^{59}$

\section{E. Analisa}

Selain lima surat yang telah dipaparkan di atas, masih terdapat beberapa surat-surat Rasulullah yang ditujukan untuk mengajak para pemimpin suatu wilayah agar bersedia menerima ajaran Islam sebagai keyakinan baru untuk pengganti keyakinan yang lama. Kelima surat Nabi Muhammad SAW. yang telah dipaparkan tersebut memang belum ada hasil yang bersifat langsung, dalam arti para penguasa tersebut langsung mengimani dan mengikuti segala yang telah diserukan oleh Rasulullah. Namun begitu upaya yang telah dilakukan oleh Rasulullah tersebut bisa dibilang sebagai tindakan yang maju pada zamannya.

59 Para ahli sejarah melihat bahwa peristiwa Perang Mut'ah ini sebagai fase baru dari gerakan kaum Muslimin Arab terhadap wilayah-wilayah yang berada di luar jazirah Arab. Perang Mut'ah yang melibatkan pasukan Syam yang dibantu dengan pasukan Romawi berhadapan dengan pasukan Muslim Arab berlangsung di suatu daerah yang menjadi perbatasan antara wilayah kekuasaan Romawi Byzantium dengan wilayah Arab. Keberhasilan umat Islam dalam peperangan besar menjelang wafatnya Rasulullah ini seolah membuka pintu bagi kaum Muslimin Arab untuk melebarkan wilayah kekuasaan dan jangkauan penyebaran ajaran Islam keluar dari wilayah Semenanjung Arabia. Lihat Al Husaini, Membangun Peradaban, Sejarah Muhammad SAW, Sejak Sebelum diutus Menjadi Nabi (Bandung: Pustaka Hidayah), 2000, hlm. 718 - 732 
Korespondensi yang berisi seruan untuk mengimani ajaran Islam yang disampaikan Rasulullah SAW. kepada Raja Heraclius, Kisra Abrawaiz, Muqouqis dan Najasyi. Memang tidak semua surat yang telah disampaikan oleh Rasulullah SAW. tersebut mendapat sambutan sebagaimana yang diharapkan, bahkan dalam beberapa surat yang disampaikan Rasulullah SAW. itu mendapatkan respon dan reaksi negatif. Dirobeknya surat Rasulullah SAW yang ditujukan kepada Kisra Abrawaiz merupakan contoh penolakan dakwah yang dilakukan. Rasulullah SAW. memaklumi dengan adanya hal tersebut, dan tidak menciutkan nyali beliau untuk selalu melakukan dakwah melalui korespondensi.

Belajar dari dakwah melalui korespondensi yang dilakukan oleh Nabi Muhammad SAW, dikatakan bahwa keberadaannya merupakan upaya untuk mengajak orang lain mengimani Allah SWT. Selain itu, korespondensi yang dilakukan juga sebagai upaya menyebarluaskan keberadaan Muhammad SAW sebagai utusanNya. Hal yang tak kalah pentingnya adalah, bahwa dakwah tidak hanya dilakukan melalui ceramah (lisan), melainkan juga melalui tulisan. Dengan demikian, media dakwah menjadi lebih banyak.

Selain catatan di atas, ada hal lain yang dapat diambil pelajaran dari adanya surat-surat dakwah yang telah dikirimkan. Ternyata, melalui korespondensi dapat dijadikan sebagai strategi dan metode dakwah yang lebih maju pada zamannya. Selain itu upaya ini adalah pembuktian nyata bahwa Islam dalam keadaan apapun juga harus dibuktikan sebagai rahmat untuk seluruh alam. Bagi Rasulullah SAW, keinginan merealisasikan Islam sebagai rahmat bagi seluruh alam selalu didengungkan dengan berbagai cara (metode), media dan strategi yang beragam. Masing-masing mempunyai sisi positif dan negatif.

Hikmah dikirimkannya surat-surat dakwah juga dijadikan sebagai upaya untuk memberikan pembelajaran kepada umat pada waktu itu untuk memperluas ajaran Islam, sekaligus meningkatkan kekuatan umat dalam ekspansi ajaran agama. Dengan melihat dunia luar, nabi berharap umatnya meningkatkan cara pandang terhadap kehidupan dunia dan agama. Penyebaran agama dijadikan sebagai momentum dalam meningkatkan kebijakan dan menambah relasi dalam berkehidupan di dunia.

Di era kekinia, berdakwah melalui korespondensi sangat terbuka lebar peluangnya. Bukan untuk melalukan hal yang sama persis dengan cara dakwah yang telah dilaksanakan oleh Nabi kepada Raja-raja, melainkan memaksimalkan media tulisan sebagai sarana dakwah. Dengan perkembangan ilmu pengetahuan dan teknologi di bidang informasi, dakwah korespondensi sangat mungkin untuk dilaksanakan. yang 
terpenting saat ini adalah cara mengisi dakwah dengan media tulisan melalui sarana teknologi. Aplikasi What up, Messanger, Face book, e mail surat kabar dan sebagainya merupakan sarana yang dapat dilakukan dalam berdakwah. Ini dapat dijadikan sebagai langkah positif dan tentunya dengan hasil yang diharapkan oleh orang-orang yang berkaitan dengan dakwah (da'i). Semoga hal ini dapat dilaksanakan.

\section{F. Kesimpulan dan Penutup}

Melaksanakan dakwah dengan berbagai media yang dipilih menjadi sebuah keniscayaan bagi seorang da'i. Dalam catatan sejarah, penggunaan media tulisan dalam berdakwah telah dilakukan oleh Muhammad SAW. Terlepas dari keberhasilan maupun kegagalan dalam berdakwah menggunakan media ini, ternyata media korespondensi mempunyai sisi yang berbeda dengan media lainnya (al-haal dan al-lisan). Terdapat karakteristik tersendiri dalam berdakwah menggunakan media yang satu ini.

Keberhasilan dakwah menggunakan media tulisan disandarkan pada pemilihan kosa kata dan bahasa yang santun. Dengan kesantunan bahasa dan kesesuaian pemahaman antara da'i dan mad'u menjadi standar penting yang tidak dapat dilupakan. Dalam konteks dakwah dengan media ini, Muhammad SAW telah memberikan tauladan, dimana faktor "utusan" menjadi faktor tambahan yang dapat digunakan untuk keberhasilan dakwah itu sendiri. Dengan utusan yang "terkenal" dan sarat dengan kepiawaian akan menjadi tambahan point dalam keberhasilan dakwah bi al-qalam.

Keberhasilan dakwah yang dilaksanakan oleh Nabi melalui al-qalam memberikan kontribusi dalam penyebaran Islam ke negara lain. Hal ini mengindikasikan bahwa ekspansi yang telah dilakukan oleh Nabi dapat dilakukan melalui dakwah yang dilancarkan olehnya. Surat kepada rajaraja yang dilayangkannya memberikan makna bahwa secara psikologis, sebagai pemimpin agama sekaligus pemimpin negara, Muhammad memiliki "prestige" tersendiri dimata pemimpin negara lainnya. Hal ini mengindikasikan bahwa keberadaan dakwah menggunakan media ini sangat bermanfaat pada masanya. Tidak hanya pada aspek penyebaran agama saja, melainkan urusan kenegaraan.

Yang menjadi penting untuk dikembangkan saat ini adalah bagaimana melaksanakan dakwah menggunakan tulisan untuk orang lain dengan menggunakan perkembangan teknologi informasi sekarang ini. 
Media sosial, seperti face book, twiter, e-mail, whats up dan sebagainya akan dapat dijadikan sebagai sarana pendukung dalam pelaksanaan dakwah bi al-qalam. Hanya saja persoalan saat ini adalah, banyak da'i yang masih kurang menangkap perkembangan teknologi, sehingga kepiawaian yang dimiliki hanya pada bagaimana menyampaikan dakwah secara lisan.

Dengan demikian, menjadi seorang da'i yang akan melaksanakan dakwah menggunakan tulisan, pada masa kini dituntut untuk bisa menggunakan perkembangan teknologi yang sedang "in". Keberhasilan dakwah menggunakan jalur tulisan tidak akan membekas apabila akumulasi antara pemilihan media dan bahasa yang baik tidak direalisasikan. Dengan berdasar pada sejarah penggunaan media korespondesi yang telah dilakukan oleh nabi, ditambah dengan peningkatan ilmu dalam dakwah akan memberikan nuansa yang berbeda bagi keberhasilan seorang da'i. 


\section{DAFTAR PUSTAKA}

Al Husaini, Al Hamid, Membangun Peradaban, Sejarah Muhammad SAW, Sejak Sebelum Diutus Menjadi Nabi (Bandung: Pustaka Hidayah), 2000.

Ali Khan, Majid, Muhammad SAW. Rasul Terakhir, Penerjemah: Fathul Umam, (Bandung: Pustaka), 1985.

Al-Khuli, Muhammad al-Bahi, Tazkirah al-Du'ah, (Mesir: Dar al-Kitab al'Arabi), 1952.

Al-Uqaili, Syaikh Uhaimid Muhammad, Surat-Surat Nabi kepada Para Raja dan Panglima Perang, Penerjemah: Wafi Marzuqi Ammar, (Surabaya: Putaka Yassir), 2011.

An-Nadwi, Abul Hasan Ali Al-Hasan, Shirah Nabawiyah, Sejarah Lengkap Nabi Muhammad SAW, Cet. ke-6, Penerjemah: M. Halabi Hamdi dkk., (Yogyakarta: Darul Manar), 2011.

Aripudin, Acep, Sosiologi Dakwah, (Bandung: PT Remaja Rosda karya), 2013.

Asy-Syafi'I, Al-Imam Syihabuddin Abi Al-'Abbas Ahmad Ibn Muhammad, Irsyaad Asy-Syaari Syarah Shahih Al-Bukhariy, Juz 6, (BeirutLibanon: Darrul kutub Ilmiyah), 1993.

Bachtiar, Wardi, Metode Penelitian Dakwah, (Jakarta: Logos), 1996.

Cangara, Hafied, Pengantar Ilmu Komunikasi, Edisi Revisi, (Jakarta: PT. Raja Grafindo Persada), 2009.

Chalil, Moenawar, Kelengkapan Tarikh Nabi Muhammad SAW. II, (Jakarta: Gema Insani Press), 2001.

Corbin, Anselm Strauss dan Juliet, Dasar-dasar Penelitian Kualitatif, Penerjemah: Muhammad Shodiq dan Imam Muttaqien, (Yogyakarta: Pustaka Pelajar), 2003.

Departemen Pendidikan dan Kebudayaan, Kamus Besar Bahasa Indonesia, (Jakarta: Balai Pustaka, 1990).

Haikal, Ahmad Muhammad Husain, Sejarah Hidup Muhammad, Cet. Ke-25, terj. (Jakarta: Pustaka Litera AntarNusa), 2001.

Hatta dkk, Ahmad., The Great Story of Muhammad SAW., OJakarta: Maghfirah Pustaka), 2011. 
Hisyam, Abdul Malik Ibnu, Shirah Nabawiyah, (Beirut: Dar al Kutub AlIlmiah), 1971.

Ilaihi, Wahyu dan Harjani Hefni, Komunikasi Dakwah, (Bandung: PT. Remaja Rosda Karya), 2010.

Mahfudz, Syekh Ali, Hidayatul Mursyidin (Mesir: Asyhar Syarif) t.t.

Purwanto, Djoko, Komunikasi Bisnis, Edisi Ke-4, (Jakarta: Erlangga), 2006.

Sa'ad, Muhammad bin Sa'ad bin Mani' al-Hasyimi al-Basri al-Ma'rufi bi ibni, thabaqat al-Khubra, Juz 1, (Beirut-Lebanon, Darul Kutub Ilmiyah), 1990.

Shihab, M. Quraish, Tafsir Al Misbah Pesan, Kesan dan Keserasian Al Qur'an, Volume 5. (Jakarta: Lentera Hati), 2002.

Subagyo, Heni, Surat-Menyurat Lengkap, (Surabaya: Amelia), 1997.

Subhani, Ja'far, Ar-Risalah: Sejarah Kehidupan Rasulullah SAW, Penerjemah: Muhammad Hasyim dan Meth Kieraha, (Jakarta: Lentera), 2000.

Supena, Ilyas, Filsafat Ilmu Dakwah: Perspektif Filsafat Ilmu Sosial. (Semarang: Absor), 2007.

Syafi'i, Muhammad Abdul Salam Abdul, Musnad Imam Ahmad Bin Hanbal, Juz 3, (Beirut-Lebanon: Darrul Kutub Ilmiyah), 1993.

Ya'cub, Ali Mustofa, Sejarah dan Metode Dakwah Nabi (Jakarta: Pustaka Firdaus), 1997.

Yunus, Mahmud, Kamus Arab Indonesia, (Jakarta: Yayasan Penyelenggara Penterjemah/Penafsir Al-Qur'an) 1973.

Zakaria, Bakar, al-Da'wah ila al-Islam, (Mesir: Dâr al-'Urulah), tt.

Zakariya, Abi al-Husain Ahmad bin Faris bin, Mu'jam Maqayis al-Lughah, (Mesir: Mushthafa al-Babi al-Halabi, 1389 H/1969) M, Juz II. 